\section{The FOMC in 1998: Can It Get any Better Than This?}

\section{David C. Wheelock}

T he U.S. economic expansion barreled into its eighth consecutive year during 1998, the longest peacetime expansion since World War II. Amidst rapid growth, inflation remained low, the unemployment rate declined to its lowest point since 1970 and real earnings rose at their fastest rate since 1972. The stock market, like the economy, continued to soar and the Federal Government budget was in surplus for the first time since 1969. The year was not unblemished, however, as recession and financial instability in Asia, Russia, and parts of Latin America roiled international financial markets during the second half of 1998. Slow growth abroad al so substantially weakened the foreign demand for U.S. products and, despite a large increase in exports during the fourth quarter, the U.S. trade deficit widened to a record for the year as a whole.

This article reviews Federal Reserve monetary policy actions and concerns during 1998. From the standpoint of monetary policy, the year's pivotal point occurred in August, when the Russian government defaulted on its domestic debt and devalued the ruble. Before August, policymakers focused on whether an explicit policy tightening would be needed to slow domestic demand enough to prevent an increase in inflation. Although inflation currently was low, extraordinarily tight labor markets, rapid growth of monetary aggregates, and strong consumer spending all seemed to point toward high- er inflation to come. Accordingly, at their meetings from M arch to July, Federal Open Market Committee (FOMC) members voted to bias their policy instructions toward a tighter policy, in effect signaling that their next explicit action would likely be a tightening move. Two committee members dissented on at least one occasion in favor of an immediate tightening.

Financial market upset triggered by the Russian government's default and devaluation of the ruble, coupled with ongoing concern about economic weakness in Asia and Latin America, caused a reevaluation of the risks to the U.S. economy during the second half of 1998. As Federal Reserve Chairman Alan Greenspan remarked before Congress on September 23, the United States cannot "remain an oasis of prosperity unaffected by a world that is experiencing greatly increased stress" (Testimony before the Committee on the Budget, U.S. Senate, "The Crisis in Emerging Market Economies," September 23, 1998). Between September and November, the Federal Reserve eased monetary policy in three successive steps to "cushion the effects on prospective economic growth in the United States of increasing weakness in foreign economies and of less accommodative financial conditions domestically" (FOMC Press Release, September 29, 1998).

This article begins by reviewing key macroeconomic outcomes for 1998. N ext, the article describes the FOMC's focus on domestic spending growth, tight labor markets, and surging money stock growth as signals of a possible increase in the rate of inflation. Finally, the article turns to a review of the discussion and decisions taken at each FOMC meeting during 1998. This section highlights, in particular, the actions taken by the FOMC during September-N ovember to accommodate increased demand for liquidity in financial markets following the Russian government's default and devaluation of the ruble, worsening economic conditions in Asia and 


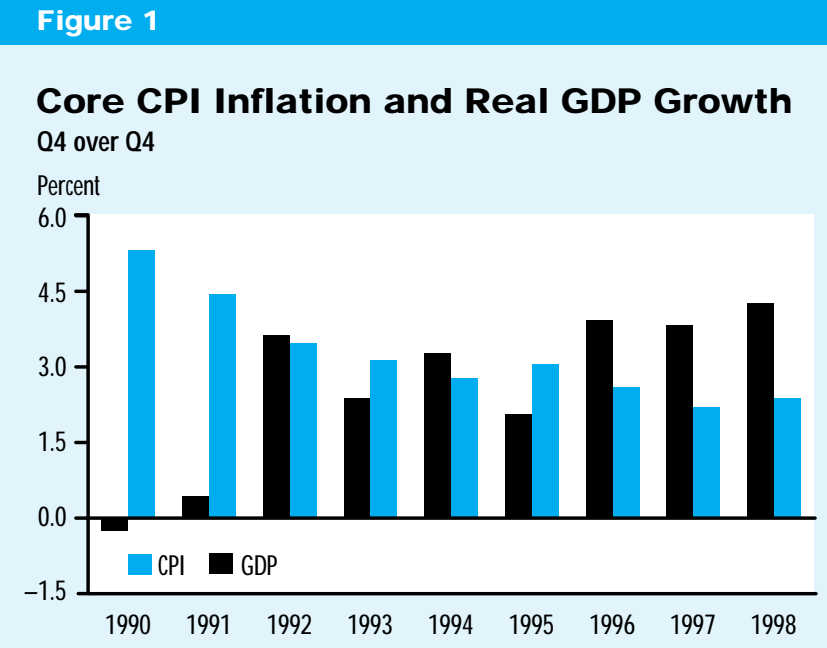

Figure 2

Core CPI Inflation and Unemployment Rate

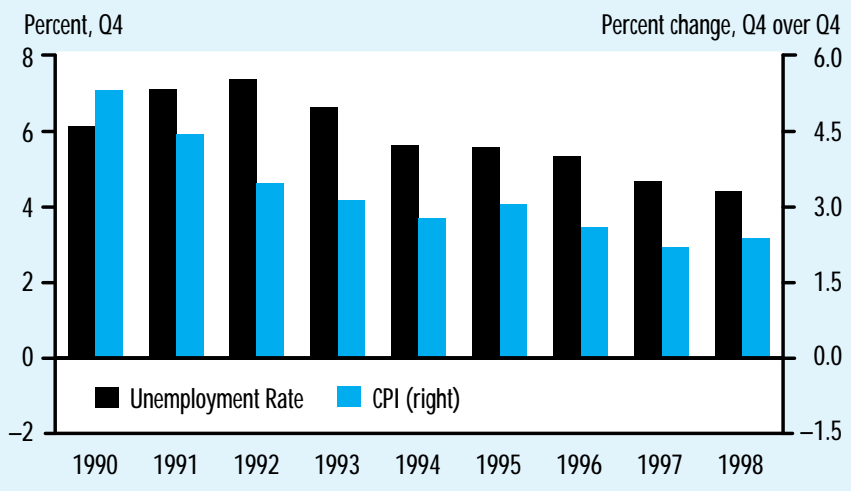

${ }^{1}$ Adjustments in the measurement of the CPI by the Bureau of Labor Statistics during 1998 accounted for 0.21 percentage points of the decline in CPI inflation between 1997 and 1998. That is, CPI inflation would have been 0.21 percentage points higher during 1998 had these adjustments not been made. See Economic Report of the President (1999, p. 94).

\section{8: A REVIEW OF THE NUMBERS} the perspective of most macroeconomic indicators. After seven continuous years of expansion, and in the face of faltering key trading partners, logic seemed to suggest that the pace of U.S. output growth had to slow. But, it did not. At 3.9 per- growth was well above its historical average rate.

During 1997, FOMC officials, like most private sector forecasters, were surprised by the economy's ability to achieve rapid growth without an increase in inflation (see Yoo, 1998). With the economy thought to be at full employment, and with ample liquidity in credit markets and rapid growth of monetary aggregates, most forecasters again predicted higher inflation during 1998. But, inflation did not rise. Instead the GDP deflator rose a mere 1.0 percent (against 1.9 percent in 1997), while the Consumer Price Index (CPI) increased just 1.6 percent (against 2.3 percent in 1997), its lowest rate since 1964. ${ }^{1}$ The unemployment rate, moreover, also fell, dipping to as low as 4.3 percent in April and December, its lowest level since February 1972. Further reflecting strength in the labor market, real average hourly earnings rose 2.74 percent, their highest increase since 1972.

Figures 1 and 2 illustrate the exemplary performance of the U.S. economy since the recession of 1990-91. The recovery from this recession has been unusual. Typically, real GDP grows rapidly during the initial recovery period, and slows to trend growth as the expansion matures. In the present recovery, however, growth was slow initially, but has since accelerated. Inflation, by contrast, has fallen with higher real GDP growth and decline of the unemployment rate. The favorable, but somewhat unusual, behavior of the economy during recent years has posed a challenge for macroeconomic policymakers-namely, to understand why the economy has performed so well and to implement policies that will best ensure continued favorable performance.

1998 was a remarkably good year from economic performance in Japan and other cent, real GDP growth in 1998 equaled its pace of 1997, which itself was a year when

\section{Monetary Policy Before August: Where's the Slowdown? Where's the Inflation?}

As 1998 began, analysts were puzzled by the fact that the Asian recession had not yet had any serious impact on the U.S. economy. Exports had declined, causing distress among some producers dependent 
on foreign markets, but strong domestic demand pushed the U.S. economy forward at a rapid pace. As unemployment dipped further with no signs of slower economic growth, many forecasters questioned whether inflation could remain low. Economists who thought that NAIRU - the acronym for "non-accelerating inflation rate of unemployment" - was approximately 5 percent of the labor force, became increasingly concerned about higher inflation as the unemployment rate dropped further below this level. Federal Reserve governor Laurence M eyer, for example, noted that his "best guess" estimate of NAIRU was $51 \frac{1}{2}$ percent, and though "spe cial forces," such as unusual declines in commodity and import prices, had held inflation temporarily in check, "the very tight labor markets can be expected to put upward pressure on wage change and hence inflation" ("The Economic Outlook and the Challenges Facing M onetary Policy," Public Policy M eeting, Federal Reserve Bank of Atlanta, April 9, 1998).

Throughout the first half of 1998, the FOMC frequently discussed the question of whether "tight labor markets" and accelerating increases in labor compensation signaled a forthcoming increase in inflation. For example, at the meeting of $\mathrm{M}$ ay 19 , the committee concluded that "The decline in the unemployment rate to its lowest level in nearly three decades underscored anecdotal reports of further tightening in labor markets in recent months and added to concerns about the outlook for inflation." At the same time, committee "members acknowledged, however, that the nexus between labor market tightness, accelerating labor costs, and the effects on price inflation was very difficult to ascertain and analyses based on earlier patterns that pointed to rising inflation had proved consistently wrong in recent years."2

Rapid and accelerating growth of monetary aggregates was a second source of concern about inflation discussed at FOMC meetings during 1998. Although the FOMC had established an annual growth rate target for $\mathrm{M} 2$ of 1-5 percent,

\begin{tabular}{|c|c|c|}
\hline \multicolumn{3}{|c|}{$\begin{array}{l}\text { Annual Percentage Growth } \\
\text { Rates of M2 and MZM } \\
\text { (Seasonally Adjusted) }\end{array}$} \\
\hline & M2 & MZM \\
\hline 1997:1 & $4.86 \%$ & $7.28 \%$ \\
\hline 1997:2 & 4.83 & 6.68 \\
\hline 1997:3 & 6.49 & 9.23 \\
\hline 1997:4 & 6.84 & 9.91 \\
\hline 1998:1 & 7.79 & 11.49 \\
\hline 1998:2 & 7.70 & 13.64 \\
\hline 1998:3 & 7.04 & 12.17 \\
\hline 1998:4 & 11.45 & 19.38 \\
\hline
\end{tabular}

M2 is the sum of currency held by the public, demand, and other checkable deposits issued by financial institutions (except those issued to the U.S. Treasury or depository institutions), travelers checks, small savings, and time deposits issued by financial institutions, and shares in retail money market mutual funds (excluding retirement accounts). MZM, i.e., "money, zero maturity," equals M2 plus institutional money market fund shares, minus small time deposits. Finally, M3 consists of M2 plus large time deposits, repurchase agreements issued by depository institutions, Eurodollar deposits, and institutional money market fund shares. The Federal Reserve sets growth targets for M2 and M3, but not for MZM. MZM, however, is frequently used for analytical purposes. Additional detail can be found in the Federal Reserve Bulletin, or Monetary Trends, a monthly publication of the Federal Reserve Bank of St. Louis.

M 2 growth exceeded 6 percent during the second half of 1997, and 7 percent during the first half of 1998. At the same time, growth of money, zero maturity (MZM), which is not targeted by the FOMC, exceeded 9 percent, rising to over 11 percent in early 1998 (see Table 1).

The FOMC sets target ranges for money stock growth. They should be viewed as benchmarks for money growth that would be associated with price stability and sustained economic expansion, assuming velocity will behave consistently with historical patterns. The FOMC has tended to downplay the usefulness of the aggregates as policy guides in recent years because velocity has behaved erratically in the past. ${ }^{3}$ N evertheless, accelerating growth of the monetary aggregates, in conjunction with other evidence that aggregate demand was increasing at an inflationary pace, caused two
2 The minutes of each FOMC meeting are published soon after the committee's next regularly scheduled meeting, and are available from the Board of Governors web site and in the Federal Reserve Bulletin.

${ }^{3}$ For evidence that the velocity of $\mathrm{M} 2$ recently has behaved more consistently with its historical pattern, see Anderson (May 1997) or Dewald (October 1998). 


\section{Figure 3}

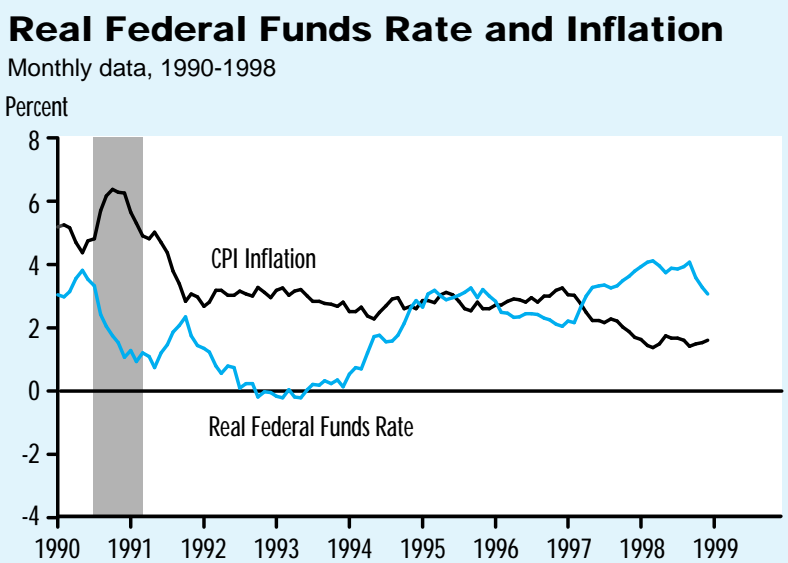

${ }^{4}$ The FOMC increased its funds rate target by 25 basis points to $54 / 2$ percent on March 25, 1997. This was the committee's only explicit policy change during that year.
FOMC members to dissent at least once in favor of moving immediately to a tighter policy stance. A majority of the FOMC, while not persuaded that rapid money stock growth alone justified a tighter monetary policy, viewed labor market tightness, rapid money growth, and perhaps other factors, as increasing the likelihood that a tighter policy would be necessary over the near term. Accordingly, at its meetings from March to July, the FOMC voted to tilt its policy directive toward a tighter policy. In introducing this asymmetry into its policy instructions, the committee refrained from an immediate, overt tightening of policy, but signaled its expectation that an actual tightening would most likely be the committee's next move.

Although the FOMC did not overtly tighten policy during 1998, by leaving its federal funds rate target unchanged, the "real" federal funds rate (measured as the difference between the nominal funds rate and the current $\mathrm{CPI}$ inflation rate) was permitted to rise as inflation fell. As Figure 3 illustrates, this continued a pattern that began during 1997.4 By this measure, monetary policy had tightened during the period, even though the Fed had not taken an explicit action. This passive tightening was not inadvertent, according to Chairman Greenspan: "The FOMC ... allowed the real funds rate to rise with continuing declines in inflation and, presumably, inflation expectations" (Testimony before the Committee on Banking, Housing, and Urban Affairs, U.S. Senate, February 23, 1999). The objective of this passive tightening of policy was to discourage an increase in inflation that might threaten continued economic expansion. As noted, however, labor markets remained tight and money growth rapid, which during the first half of 1998 left policymakers concerned that passive tightening would not prevent an increase in inflation.

Exceptional growth of output and employment, without an increase of inflation, defied conventional economic rulesof-thumb during 1998. The year proved, once again, the folly of relying solely on the stability of either output (or employment) gap or monetary aggregate growth rate relationships with near-term inflation. Economists are aware that such relationships can break down for a variety of reasons. Since the early 1980s, for example, financial innovations have rendered unstable the relationship between short-run changes in narrow monetary aggregates, such as $\mathrm{M} 1$, and inflation. During 1998, unusual gains in productivity appear to explain how output growth could rise as fast as it did, and the unemployment rate fall as much as it did, without an increase in the rate of inflation.

In congressional testimony, Federal Reserve Chairman Alan Greenspan argued that the United States has enjoyed a "virtuous cycle" of investment-driven productivity gains stimulated by low inflation and optimistic expectations about future economic growth. Productivity growth then, in turn, has fueled expectations of future economic returns, prompting further investment, and so forth:

Evidence of accelerated productivity has been bolstering expectations of future corporate earnings, thereby fueling still further increases in equity values, and the improvements in productivity have been helping to reduce inflation. In the context of subdued price increases and generally supportive credit conditions, rising equity values have provided impetus to spending 
and, in turn, the expansion of output, employment, and productivity-enhancing capital investment. (Testimony before the Committee on Banking, Housing and Urban Affairs, U.S. Senate, July $21,1998)$

Figures 4 and 5 provide two measures of productivity growth- nonfarm business productivity growth and manufacturing productivity growth. Typically, productivity growth declines, and may turn negative, as the economy enters a recession. Productivity growth then increases sharply late during the recession and initial recovery phase. Although volatile, productivity growth often falls as the expansion matures.

As is typical, productivity growth surged during the initial year of recovery from the 1990-91 recession. After little growth in 1993-95, however, productivity increased sharply beginning in 1996 and could, in principle, explain the simultaneous increase in real earnings and output growth and the decline in inflation. Indeed, the recent surge raises the question of whether the long-run, or trend, rate of productivity growth has increased. If it has, then the economy's long-run potential growth rate is higher than the approximately $2^{1 / 2}$ percent pace that economists thought possible. And, the "natural" rate of unemployment may now be closer to the 4- 41/2 percent rate of the 1960s than to $51 / 2-6$ percent, the rate economists widely believe prevailed during the 1980s. A number of model-based estimates of the natural rate of unemployment, however, currently remain in the $51 / 4-51 / 2$ percent range.

Forecasting changes in the trend growth of productivity, or even measuring the true level of productivity at any point in time, is notoriously difficult (see, e.g., Griliches 1994). Unfortunately, mismeasuring productivity trends, and hence, potential output growth, can have serious implications for monetary policy. For example, suppose policymakers follow a rule of easing policy whenever the observed rate of GDP growth falls below its assumed potential rate. Then, suppose that an unexpected decline in productivity growth causes both actual and

\section{Figure 4}

Nonfarm Business Productivity Growth Quarterly data, 1960-1998

Percent

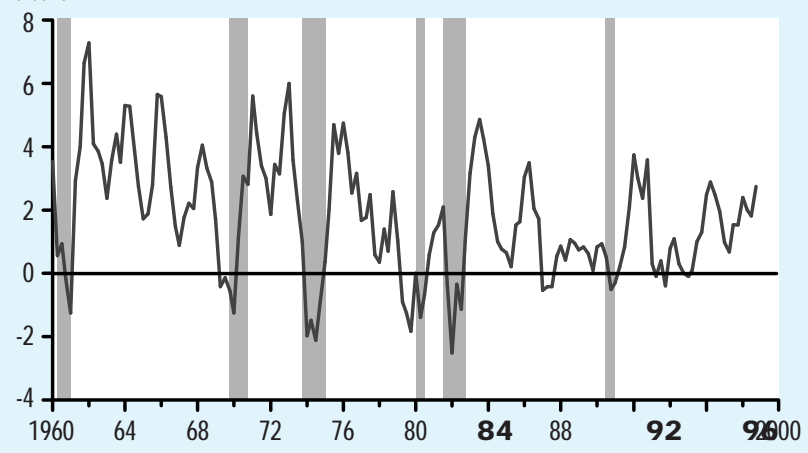

\section{Figure 5}

Manufacturing Productivity Growth

Quarterly data, 1960-1998

Percent

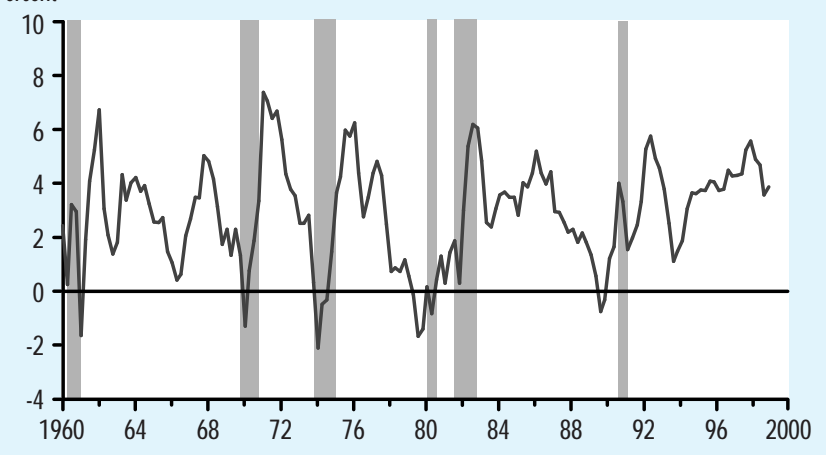

potential GDP growth to fall simultaneously and proportionately, so that the output gap has not changed. Unless policymakers understand immediately that potential growth has fallen, and revise their assumptions accordingly, they will ease monetary policy. Such an action could prove destabilizing, however, causing a higher rate of inflation for a given rate of GDP growth, than would occur if no action were taken.

During 1998, Fed officials faced simiIar uncertainty about potential output. If the combination of rapid output growth and low inflation reflected a permanent increase in the rate of productivity growth, a tighter monetary policy might cause output growth to fall temporarily below 
${ }^{5}$ See Orphanides (1998) for a formal analysis of the effects of measurement uncertainty on optimal monetary policy.

${ }^{6}$ Although theoretically appealing, an empirical relationship, either positive or negative, between inflation and long-run real economic growth has been found to depend on the choice of countries studied as well as the time period and estimation method. See Barro (1996) and Bruno and Easterly (1996) for two recent empirical studies of this relationship.

${ }^{7}$ The FOMC consists of the seven members of the Board of Governors of the Federal Reserve System and the presidents of the 12 Federal Reserve Banks. Only five Reserve Bank presidents are voting members of the committee, however. The president of the Federal Reserve Bank of New York is always a voting member, and serves as the committee's vice chair, while the remaining Reserve Bank votes are rotated among the other 11 Reserve Bank presidents.

\footnotetext{
${ }^{8}$ All quotations in this section are from the minutes of the various FOMC meetings.
}

its potential, and possibly put downward pressure on the price level. On the other hand, if recent gains in productivity are only temporary, failure to tighten monetary policy when the economy is growing at such a rapid pace could result in an eventual increase in inflation. Indeed, an increase in inflation could erode productivity growth, possibly resulting in lower potential output growth over time. ${ }^{5}$

Because higher inflation might discourage productivity-enhancing investment and lessen the economy's growth potential, price stability has become an increasingly important objective of monetary authorities in many countries. Several countries, as well as the European Monetary Union, have made price stability the sole objective of monetary policy. This emphasis reflects, at least in part, the now widely held view that a credible commitment to preserving price stability best promotes maximum economic growth over the long term. Chairman Greenspan argues that the "virtuous cycle" that has propelled the strong U.S. economy was an outcome of reducing inflation to near zero:

The essential precondition for the emergence, and persistence, of [the] virtuous cycle is arguably the decline in the rate of inflation to near price stability. ... Risk premiums and economic disincentives to invest in productive capital diminish as the economy approaches price stability. ... Technological innovations and the rapidly declining cost of capital equipment that embodies them in turn seem to be a major factor behind the recent enlarged gains in productivity. (Testimony before the Committee on Banking, Housing, and Urban Affairs, U.S. Senate, July 21, 1998)

The possibility that inflation might, in fact, hamper growth, explains why preserving price stability has become the paramount objective of monetary policy in central banks throughout the world. ${ }^{6}$ And, it was a concern that a reemergence of inflation might endanger the ongoing economic expansion that proved to be the central focus of FOMC policy deliberations during the first seven months of 1998.

Table 2 summarizes the FOM C's decisions during 1998, as reflected in the policy directives issued by the FOMC to the open market trading desk. It also lists the voting members of the committee. ${ }^{7} \mathrm{~A}$ review of the issues that seemed to weigh heavily in the discussion at each meeting during the first half of 1998 follows. ${ }^{8}$

February 3-4. At the first FOMC meeting of the year, the committee discussed current economic data and the staff forecast for the year ahead. The staff predicted that the economic expansion would "slow appreciably" over the next several quarters, primarily because slower growth abroad and appreciation of the dollar would substantially reduce the demand for U.S. exports. Despite slower output growth, however, inflation was forecast to increase somewhat as declines in energy and import prices were expected to abate.

The FOMC members agreed that the economy was likely to slow during 1998, with a prospective decline in exports and moderation in the growth of business inventories cited as the principal causes. The committee concluded, however, that the "risks of a considerable deviation on the upside or the downside of their current forecasts were unusually high," and that "the potential extent of the negative effects of developments in Asia on the nation's trade balance represented key uncertainty in the economic outlook."

The FOMC members al so expressed uncertainty regarding the present stance of monetary policy. They noted that the real federal funds rate was unusually high, but that "financial conditions seemed to be quite stimulative as evidenced by lower nominal and perhaps real intermediate and long-term interest rates, rising equity prices, ready credit availability, and rapid growth of the broad measures of money and credit." In the face of these uncertainties, the FOMC decided unanimously to leave the current stance of policy unchanged by retaining its current target for the federal funds rate of $51 / 2$ percent. 


\section{Table 2}

\section{Summary of FOMC Decisions in 1998}

\begin{tabular}{|c|c|c|c|}
\hline Meeting Date & $\begin{array}{c}\text { Federal Funds } \\
\text { Rate Target }\end{array}$ & Intermeeting Stance & Dissents \\
\hline February 3-4 & 5.50 & symmetric & none \\
\hline March 31 & 5.50 & asymmetric (tighter) & Jordan \\
\hline May 19 & 5.50 & asymmetric (tighter) & Jordan, Poole \\
\hline June 30-July 1 & 5.50 & asymmetric (tighter) & Jordan \\
\hline August 18 & 5.50 & symmetric & Jordan \\
\hline September 29 & 5.25 & asymmetric (easier) & none \\
\hline October 15* & 5.00 & not applicable & not applicable \\
\hline November 17 & 4.75 & symmetric & Jordan \\
\hline December 22 & 4.75 & symmetric & none \\
\hline
\end{tabular}

* October 15 was not a regularly scheduled meeting of the FOMC, but rather a conference call in which the members agreed that the federal funds rate target should be reduced by 25 basis points.

\section{Members of the Federal Open Market Committee in 1998}

Alan Greenspan, Chairman. Chairman of the Board of Governors of the Federal Reserve System

William J. McDonough, Vice Chairman. President of the Federal Reserve Bank of New York

Roger W. Ferguson, Jr. Governor of the Federal Reserve System

Edward M. Gramlich. Governor of the Federal Reserve System

Thomas M. Hoenig. President of the Federal Reserve Bank of Kansas City

Jerry L. Jordan. President of the Federal Reserve Bank of Cleveland

Edward W. Kelley, Jr. Governor of the Federal Reserve System

Laurence H. Meyer. Governor of the Federal Reserve System

Cathy E. Minehan. President of the Federal Reserve Bank of Boston

Susan M. Phillips.** Governor of the Federal Reserve System

William Poole.** President of the Federal Reserve Bank of St. Louis

Alice M. Rivin. Vice Chairman of the Board of Governors of the Federal Reserve System

** Ms. Phillips resigned from the Board of Governors of the Federal Reserve System during 1998, and attended her last meeting on May 19. Mr. Poole was appointed President of the Federal Reserve Bank of St. Louis on March 23, and attended his first FOMC meeting on March 31. Robert D. McTeer, Jr., President of the Federal Reserve Bank of Dallas, voted as an alternate member of the FOMC at the meeting of February 3-4.

March 31. By the second meeting of 1998, a majority of the FOM C had become less optimistic about the outlook for inflation. Despite continued projections from the staff that the economic expansion would slow appreciably over the near term, FOMC members concluded that

... domestic demand was exceeding expectations and was likely to continue to increase rapidly for some time, supported by accommodative conditions in key segments of financial markets. Developments in foreign trade were moderating demands on domestic resources; but with domestic spending strong, members were becoming more concerned that those developments might not exert enough restraint on aggregate demand to slow the expansion to a sustainable pace.

Consequently, "the members agreed that should the strength of the economic expansion and firming of labor markets persist, policy tightening likely would be 
needed at some point to head off imbalances that over time would undermine the expansion in economic activity." As a result, the committee voted to maintain the prevailing federal funds target of $51 / 2$ percent, but to adopt an asymmetrical directive tilted toward a tighter policy.

Jerry L. Jordan, President of the Federal Reserve Bank of Cleveland, dissented from the policy directive adopted at the M arch 31 meeting. In his view, prevailing rapid money stock growth was likely to reignite inflation and, thus, the FOMC should tighten policy immediately.

May 19. At the FOMC meeting of May 19 , Jordan again dissented in favor of an immediate tightening of monetary policy. He was joined by William Poole, President of the Federal Reserve Bank of St. Louis. Both presidents felt that, unless checked, rapid money stock growth would bring about an increase in the rate of inflation and ultimately threaten the economic expansion.

A majority of the FOMC, however, concluded that the outlook for inflation and continued economic expansion was too uncertain to warrant an immediate change in monetary policy. The committee noted that the economy was continuing to grow more rapidly than had been forecast, or than was sustainable over the long run. N evertheless, as the committee staff continued to predict, most FOMC members were persuaded that economic growth would moderate appreciably during the coming quarters. Moreover, there was concern that an explicit tightening of policy by the Fed "could have outsized effects on the al ready very sensitive financial markets in Asia," with the resulting "unsettlement" having "substantial adverse repercussions on U.S. financial markets and, over time, on the U.S. economy." In light of these concerns, the FOMC elected not to change the current stance of monetary policy. At the same time, the committee agreed to retain a bias in its operating directive towards a tighter policy, which reflected a consensus that the balance of risks indicated that the next explicit policy action would be a tightening move in order to ward off an increase in inflation.
June 30-July 1. Information available at the time of the FOMC meeting of June 30-J uly 1 suggested that the rapid pace of economic activity had slowed. A strike at General Motors was expected to substantially reduce the nation's industrial production during June. Preliminary indications were that business inventory accumulation also had fallen substantially during the second quarter, as did business fixed investment. The trade deficit also continued to increase, further suggesting that output growth had slowed during the second quarter. On the other hand, labor markets remained exceptionally tight, with substantial increases in employment outside of manufacturing. Retail sales also continued to increase strongly. In light of mixed signals from the nonfinancial side of the economy, and with monetary and credit aggregates continuing to grow strongly, the FOMC elected to continue to "wait and see" before making an explicit change in policy. The committee did, however, retain its bias towards a tighter policy and, once again, President Jordan dissented from the committee's decision in favor of an immediate tightening of policy.

\section{RESPONDING TO \\ FINANCIAL SHOCKS}

August 18. "Wait and see" was again the outcome of FOMC deliberations on August 18. Further evidence of domestic slowing, coupled with further economic deterioration in Japan and other Asian countries, and a partial debt default and currency devaluation by Russia on August 17 received the committee's focus. Although consumer spending and nonmanufacturing job growth remained strong, retail sales and industrial production declined in July, even with adjustment for the effects of the General Motors strike.

Perhaps most alarming to the committee was the deterioration in foreign economies: "In Japan ... economic activity appeared to have contracted sharply further during the second quarter. In most other Asian economies, currencies and equity prices were under downward pres- 
sure, and in Russia, asset values plummeted in often disorderly markets. Risk spreads on dollar-denominated debt widened substantially, not only in Russia but for Latin American issuers as well."

Regarding the near-term outlook for the domestic economy, FOMC members pointed out that "unusually favorable underlying factors, including solid ongoing gains in employment and incomes and substantial further increases in household net worth" suggested that domestic demand for goods and services was unlikely to moderate substantially anytime soon. Moreover, "business fixed investment also seemed to be on a solid upward trajectory" and construction activity remained high. On balance, a majority of the committee concluded that "Greater difficulties abroad and associated downward pressures on demand and prices had substantially diminished the chances of a strengthening of inflation pressures over coming months and quarters that would require a nearterm tightening of policy." A minority, however, felt that the risks remained weighted toward an increase in inflation. Nevertheless, while not changing its target for the federal funds rate, the FOMC removed the bias in its directive towards a tighter policy. Once again, President Jordan dissented, "because he believed that the underlying strength of aggregate demand in the U.S. economy would remain fundamentally intact, despite economic problems abroad," and "continued rapid growth in the money supply creates the risk that inflation will accelerate."

September 29. Global financial markets became increasingly unsettled during September and early October, precipitating a "flight to quality" of funds from relatively high risk, illiquid securities toward less risky, more liquid instruments. Yields on U.S. Treasury securities plunged, while those on high-quality corporate offerings declined less, and those on some low-quality securities rose. Figure 6 illustrates this phenomenon, showing the increases in average yields on Aaa and Baa-rated corporate bonds relative to the yield on 10-year U.S. Treasury securities, and the increased

\section{Figure 6}

U.S. Bond Market Quality Spreads

Daily data, January 1998 to January 1999

Percentage points

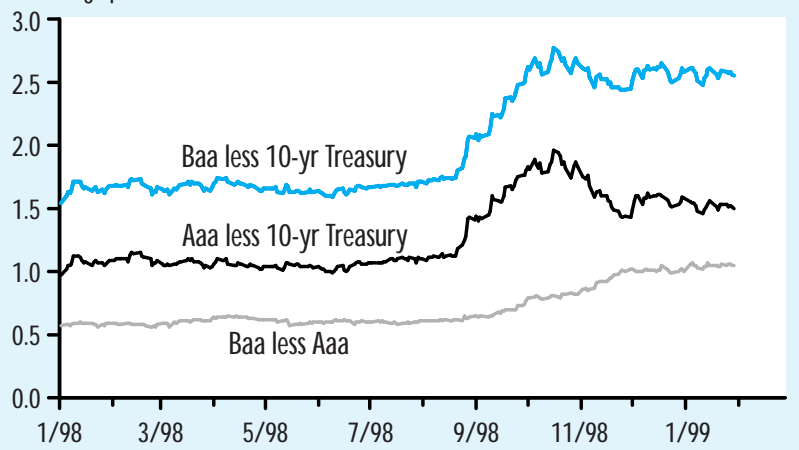

\section{Figure 7}

Short-Term Interest Rates

Daily data, January 1998 to January 1999

Percentage points

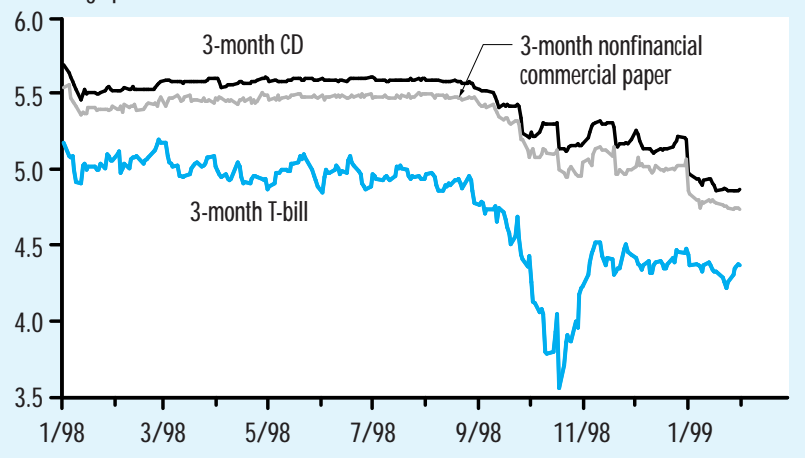

\section{Figure 8}

U.S. Bonds Market Quality Spreads

Daily data, January 1994 to January 1999

Percentage points

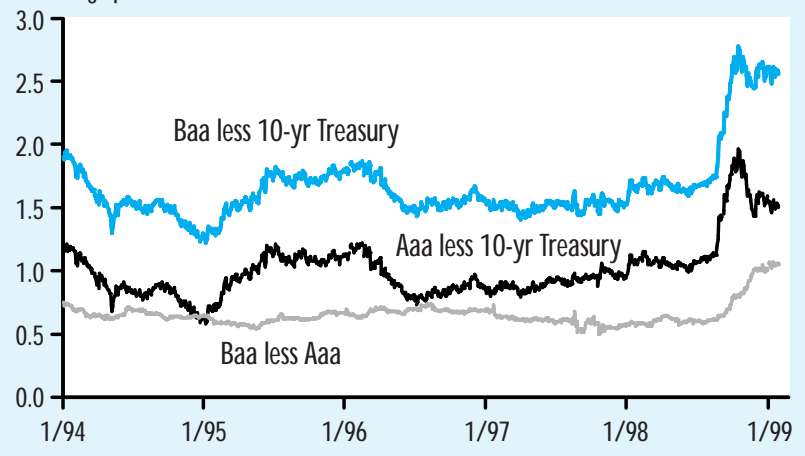


spread between Aaa and Baa-rated yields. Yield spreads among short-term securities similarly increased, as Figure 7 illustrates by plotting the three-month Treasury bill yield against average rates on three-month bank certificates of deposit and threemonth nonfinancial commercial paper. Finally, Figure 8 shows that, by the standard of the previous five years, bond market yield spreads during the fall of 1998 were unusually high.

Along with the flight to quality, anecdotal reports indicated that many relatively low quality borrowers were unable to obtain funds in the money market. Although many borrowers were accommodated by drawing down existing lines of credit at commercial banks, a special survey of senior bank loan officers, conducted by the Federal Reserve in September, indicated that banks had tightened their standards for loans to large firms. According to the survey, "The banks that reported having tightened their lending standards and terms most commonly attributed their decision to a less favorable economic outlook and a worsening of industry-specific problems, as well as a reduced tolerance for risk." Thus the survey results were consistent with the evidence from credit markets that lenders were increasingly fearful about the prospects for continued economic expansion in the United States, and had become less willing to take financial risks.

In light of growing instability in financial markets and a weakened outlook for continued domestic expansion, the FOMC voted to adopt a more stimulative monetary policy by reducing its federal funds rate target from $5 \frac{1}{2} / 2$ percent to $5 \frac{1}{4}$ percent. "In the Committee's discussion of current and prospective economic conditions, members focused on developments that pointed to the potential for a significant weakening in the growth of spending." The members concluded that "the downside risks to the domestic expansion appeared to have risen substantially in recent weeks." And, "It was clear that the contagious effects of international economic and financial turmoil had markedly increased the downside threat to the domestic expansion."

In considering policy, the FOMC discussed the continued rapid growth of monetary aggregates. While it was suggested that "rapid growth of key monetary aggregates, including M2, over a period of several quarters was a worrisome element in the outlook for inflation," surges in the money stock during the most recent weeks were seen as likely caused by the flight to quality and increased demand for liquidity. Thus, policymakers concluded "an easing policy action at this point could provide added insurance against the risk of a further worsening in financial conditions and a related curtailment in the availability of credit to many borrowers."

Thus the sudden instability in global financial markets had led the FOMC to reevaluate the risks to continued economic expansion in the United States. Prior to the onset of financial instability, higher inflation was viewed as the most likely threat to continued economic growth. Inflation imposes serious economic costs, and history indicates that the more entrenched inflation becomes, the more difficult it is to bring down. The sudden threat to domestic financial markets and economic activity from abroad, however, reduced the risk of an immediate increase in inflation. By increasing the cost and reducing the availability of credit to private borrowers, as well as by increasing uncertainty about the economic outlook, financial instability threatened to slow U.S. economic activity appreciably. Thus the Fed sought to ensure an ample supply of liquidity to financial markets to counteract this threat.

October 15 Conference Call. When the FOMC voted to reduce its federal funds rate target on September 29, it also approved a directive tilted toward additional easing. Further deterioration of financial conditions in the ensuing two weeks led the FOMC to approve a second 25 basis point reduction in the funds rate target to 5 percent. The committee concluded that additional stimulus was needed because ... risk aversion in financial markets had increased further since the Com- 
mittee's meeting in September, raising volatility and risk spreads even more, eroding market liquidity, and constraining borrowing and lending in a number of sectors of the financial markets. Although indications of any softening in the pace of the economic expansion across the country remained sparse, the widespread signs of deteriorating business confidence and evidence of less accommodative domestic financial conditions suggested that the downside risks to the expansion had continued to mount.

In conjunction with the federal funds rate target reduction, the Board of Governors approved a reduction of Reserve Bank discount rates from 5 percent to $43 / 4$ percent.

N ovember 17 . In reviewing the state of financial markets and the latest information about the prospects for continued economic expansion at its meeting on N ovember 17, the FOMC observed that while financial market "strains" had moderated since midOctober, "uncertainty remained high and relatively illiquid conditions persisted." M oreover, while recent data indicated that the economy was continuing to grow rapidly, the FOMC staff forecast "considerable slowing" on the horizon, and FOMC members "generally agreed that the economy appeared to be headed toward slower growth." And, they "believed that the continuing fragility of financial markets and the increased scrutiny of the credit quality of borrowers ... posed a considerable downside risk to the expansion." Because of this, the FOMC elected to ease policy once again by reducing its target federal funds rate 25 basis points to $43 / 4$ percent. The committee concluded that this move would "complete the policy adjustment to the changed economic and financial climate that had emerged since midsummer and would provide some insurance against any unexpectedly severe weakening of the expansion." M oreover, "most members saw little risk that a modest easing would ignite inflationary pressures in the economy." Federal Reserve Bank of Cleveland president Jerry Jordan dissented, however, arguing that the additional easing "risked fueling an unsustainably strong growth rate of domestic demand." Easing, he believed, would cause "excessively rapid rates of growth of the monetary and credit aggregates [that] were inconsistent with continued low inflation."

December 22. At their December meeting, FOMC members remain convinced that "The System's policy easing actions since late September had hel ped to stabilize a dangerously eroding financial situation, and current financial conditions as well as underlying economic trends suggested that needed policy adjustments had been completed." In deciding against acting further, policymakers observed that al though financial markets remained "unusually sensitive," domestic financial conditions would support continued economic expansion. Some committee members believed, moreover, that "the risks of inflation appeared to be tilted to the upside." Nonetheless, some slowing of the economy during the next 12 months still was expected and, overall, the outlook for inflation remained "favorable." Hence, all FOMC members agreed that policy was best left unchanged at this meeting.

\section{CONCLUSION}

Like 1997, 1998 proved to be a year of outstanding economic performance for the United States-rapid output and employment growth, rising real wages, and low, stable inflation. This strong performance reflected productivity gains that enabled the real earnings of labor to rise, while both unemployment and inflation fell. Arguably, monetary policy has encouraged the economy's strong performance by reducing inflation to a low level, and during 1998, policymakers were keenly interested in maintaining a lid on inflation to promote continued economic expansion. Thus, in the first half of 1998, high levels of domestic spending, tight labor markets, and rapid growth of monetary aggregates caused the FOMC to signal that its next overt policy move would likely be tightening. Two members of the FOMC were, at the 
same time, sufficiently concerned about an increase in inflation to vote (at least once) in favor of immediate tightening.

Attention changed abruptly in the autumn, when economic and financial instability abroad precipitated a scramble for liquidity and safety affecting U.S. financial markets. The FOMC accommodated the increased demand for liquidity by easing policy on three occasions. These actions were taken not just to assuage financial markets, but to preserve the ongoing economic expansion. The fourth quarter witnessed rapid growth of real output, as well as continued low inflation, and financial markets calmed. Chairman Greenspan testified in February 1999 that "Our economy has weathered the disturbances with remarkable resilience," and argued that "The Federal Reserve must continue to evaluate ... whether the full extent of the policy easings undertaken last fall to address the seizing-up of financial markets remains appropriate as those disturbances abate." (The Federal Reserve's Semiannual Report on Monetary Policy, Testimony of Chairman Alan Greenspan before the U.S. Senate Committee on Banking, Housing, and Urban Affairs, February 23, 1999). As Chairman Greenspan implied, the challenge for policymakers is to look forward and continually reevaluate whether the stance of monetary policy remains appropriate as conditions change. In 1998, the FOMC moved decisively when financial disturbances threatened the U.S. expansion, but held off earlier in the year when traditional indicators suggested that inflation might increase. Throughout 1998, economic conditions remained favorable. But, in light of the old saying that the lag effects of monetary policy on the economy are "Iong and variable," only time will tell whether the policy actions taken in 1998 will turn out to be consistent with preserving price stability and maximum sustainable economic growth over the long run.

\section{REFERENCES}

Anderson, Richard G. "Is M2 Growth on a New Track?" Monetary Trends (May 1997).

Barro, Robert). "Inflation and Growth," this Review (May/ June 1996), pp. 153-69.

Bruno, Michael, and William Easterly. "Inflation and Growth: In Search of a Stable Relationship," this Review (Mayl June 1996), pp. 139-46.

Dewald, William G. "M2 Velocity Looks to be on a New Track," Monetary Trends (October 1998).

Griliches, Zvi. "Productivity, R\&D, and the Data Constraint," American Economic Review (March 1994), pp. 1-23.

Orphanides, Athanasios. "Monetary Policy Evaluation with Noisy Information," Board of Govemors of the Federal Resenve System, Finance and Economics Discussion Series no. 1998-50, October 1998.

Yoo, Peter. "The FOMC in 1997: A Real Conundrum," this Review (September/ October 1998), pp. 2740. 